\title{
Forest Structure, Diversity and Regeneration Pattern Along Altitudinal Gradient in Temperate Zone of Nanda Devi Biosphere Reserve (a World Heritage Site), Western Himalaya, India
}

Ajay Maletha ( $\square$ maletha.jay@gmail.com )

GBPIHED

\section{Rakesh Kumar Maikhuri}

HNBGU: Hemwati Nandan Bahuguna Garhwal University

Surendra Singh Bargali

Kumaun University Uttarakhand

\section{Research}

Keywords: Temperate forest, Population structure, Species composition, Regeneration status, NDBR, Western Himalaya

Posted Date: January 5th, 2021

DOI: https://doi.org/10.21203/rs.3.rs-138856/v1

License: (우 (i) This work is licensed under a Creative Commons Attribution 4.0 International License. Read Full License 


\section{Abstract}

\section{Background}

The present study exhibited forest structure, plant species composition and regeneration pattern in temperate zone of Nanda Devi Biosphere Reserve (NDBR), western Himalaya along the different altitudinal gradient ( 2600 to $3600 \mathrm{~m}$ asl). The diverse ecosystems of the NDBR contain a tremendous array of floral and faunal diversity, many of which are rare and endangered species.

\section{Results}

A total of 223 species of vascular plants (Angiosperm, Gymnosperm and Pteridophytes) were identified within the study area. Rosacaeae (17.69 \%) family was exhibited dominant followed by Asteraceae $(14.97 \%)$ and Ranunculaceae (12.93\%). Among all the plant species, Betula utilis had highest tree density (724 \& 324 individuals ha ${ }^{-1}$ in each site) and contributed maximum dominance of species cover ( $44 \%$ and $36 \%$ ) at Tolma and Ghangaria sites followed by Pinus wallichiana (24\%) and Cedrus deodara (15\%), respectively. In Ghangaria site, $56 \%$ tree species showed fair regeneration, $22 \%$ good, $11 \%$ exhibited poor and remaining (11 $\%$ ) indicated no regeneration while at Tolma site, $40 \%$ species showed fair regeneration, $40 \%$ good and remaining $20 \%$ no regeneration.

\section{Conclusion}

Our results suggest to monitor the change in vegetation structure, species composition and regeneration pattern, we should establish permanent study plots in different forest types located along the elevational gradients for an effective and comprehensive monitoring programme to tracks the response of changing climate at both community and species level. Therefore, it is necessary to development of appropriate weather and meteorological station in this sensitive and ecologically important area for regional projection of micro climatic condition and generation of scientific data on changing vegetation composition and advancement of the native species.

\section{Background}

The Himalayas regions most diverse ecosystem on the earth with a variety of plants species, high endemism and forest types due to the wide altitude gradient, topography, soil, climate and geographical location (Mani 1978; Kharkwal 2005; Sharma et al. 2009, 2010a; Chandra et al. 2010; Gairola et al. 2011a). Indian Himalayan region cover about 5 lakh km2 (about $16.2 \%$ of country's total geographical area) and forms the northern boundary of the country. Himalayan region recognized as one of the hotspots of biodiversity and harbors nearly 8,000 species of flowering plants, of which $25.3 \%$ are endemic (Singh and Hajra 1996). Forest structure, species composition and regeneration patterns are most crucial ecological attributes of healthy forest ecosystems which exhibit variations in response to change in climate as well as anthropogenic complexities (Gairola et al. 2008; Krauchi et al. 2000; Dolezal and Srutek 2002). Elevation play major role to determine the structure of vegetation in most mountain of the world (Zhang et al. 2006; McVicar and Korner 2012). However, several studies have been carried out to assess the qualitative and quantitative characters 
of the vegetation in Western Himalaya (Saxena and Singh 1982; Rawal and Pangtey 1994; Baduni and Sharma 1996; Dhar et al. 1997; Rawat et al. 2001; Adhikari et al. 2004; Joshi et al. 2004), and other parts of the world (Shaw 1909; Goldsmith and Smith 1926; Griggs 1938; Allen and Walsh 1996; Holtmeier 2003; Schickhoff 2005), mostly revealed hump shaped (high species diversity at middle of gradient) distribution of species (Austrheim 2002; Zhang and Ru 2010). The population structure, characterized by the presence of sufficient population of seedlings, saplings and adults, indicates successful regeneration of forest species (Marks 1974; Vablen et al. 1979; Pritts and Hancock 1983; Saxena et al. 1984; Khan et al. 1987), and the future composition of the forests depends on the potential regenerative status of tree species within a forest stand in space and time (Henle et al., 2004). The studies on forest composition, structure, plant diversity and regeneration of different part of NDBR have been studied but particularly in Ghangaria and Tolma sites of present study has so far not been analysed along altitudinal gradients. The Tolma site is way to approach the core zone of the reserve and old trekking route of the tourist before the notification as reserve. However, the Ghangaria site influenced by the Sikh pilgrims (visited to Hemkund Sahib, sacred place of Sikh community), tourist visited Valley of Flower National Park (another core zone of the reserve) and inhabitants who has constructed permanent and temporary shops, lodges and small hotel and restaurants for income generation during summer season.

The hypothesis of the present study was that: (i) Forest structure, species composition and regeneration status change along the altitudinal gradient up to timberline ecotone (ii) Does altitude influence the species diversity?. To test the hypothesis, the following objectives were envisages: (i) To assess the forest structure, species composition and regeneration status of forest stand along altitudinal gradient. (ii) To assess the physiochemical properties of soil with relation to the forest stand. Therefore, present study expected to provide scientific information and baseline data that can be used for halt the biodiversity and help to develop the effective conservation and management plans for these ecological sensitive ecosystems.

\section{Materials And Methods}

\section{Study site}

The study was conducted at two different sites of Nanda Devi Biosphere Reserve (NDBR) timberline ecotone viz., (A) Ghangaria and (B) Tolma region (buffer zone), covering an area between $30^{\circ} 16^{\prime} \mathrm{N}$ to $30^{\circ} 41^{\prime} \mathrm{N}$ and $79^{\circ} 33^{\prime} \mathrm{E}$ to $79^{\circ} 44^{\prime} \mathrm{E}$ with elevation ranges from $2800 \mathrm{~m}$ to $3400 \mathrm{~m}$ asl in the Central Himalaya. This biosphere reserve was recognized as a World Heritage Site in 1992 and was included in the UNESCO's world network of Biosphere Reserves in 2004. The reserve covers an area of about $5860 \mathrm{~km}^{2}$ with two core zones the Nanda Devi National Park (624.62 sq. km) and the Valley of Flowers National Park (87.50 sq km). There are three seasons-summer (April-June), rainy season (June -September), and winter (October-March), and the average annual rainfall is $928.81 \mathrm{~mm}$. About $47.8 \%$ of the annual rainfall occurs over a short period of two months (July-August) due to the strong influence of the monsoon. The maximum temperature ranges from 11 to $24{ }^{\circ} \mathrm{C}$ and the minimum from 3 to $7.5^{\circ} \mathrm{C}$ (Fig. 1). The altitudinal range of the biosphere reserve varies from $2,100 \mathrm{~m}$ asl to $7,817 \mathrm{~m}$ asl.

\section{Vegetation sampling}


Vegetation analysis was carried out by using stratified random design sampling at two sites of timberline area in NDBR. A total of 146 plots (73 in each site) of $10 \mathrm{~m} \times 10 \mathrm{~m}$ were laid randomly between $2600 \mathrm{~m}$ asl to $3600 \mathrm{~m}$ asl for enumeration of tree species. Each plot $(10 \times 10 \mathrm{~m})$ was further subdivided into $5 \mathrm{~m} \times 5 \mathrm{~m}$ sub-plots for enumeration of shrub and saplings, and $1 \mathrm{~m} \times 1 \mathrm{~m}$ for seedlings and herb species (Misra 1968). The vegetation data were quantitatively analyzed for abundance, density and frequency according to Curtis and McIntosh (1950) and Misra (1968). The relative values were summed up to represent important value index (IVI) given by Curtis (1959). The diversity index (H') was computed by using Shannon-Weaver information Index (Shannon and Weaver, 1949). The regeneration status of dominant tree species was assessed based on the proportional distribution of density of individuals in each seedling, sapling and adult tree). The regeneration status of tree was considered "good" when seedling density > sapling density > adult tree density, "fair" when seedling density > sapling density $\leq$ adult density, "poor" when the species survived in only the sapling stage but not in the seedling stage, "none", for species with no sapling or seedling stages but present as adult trees, and "new" when adults of a species were absent but sapling and/or seedling stage(s) were present (Shankar 2001; Paul 2008).

\section{Physiochemical properties of soil}

The soil analysis of different aspect of the study area was conducted to determine the physiochemical characteristics of soil at different altitude gradient. The moisture percentage, water holding capacity (\%) and texture of soil was determined as the methods described by Misra (1968). Soil pH (1:2.5, soil: water) was used to measure with the help of dynamic digital pH meter. Soil organic carbon (\%) was determined by Walkley and Black's rapid titration method (Walkley and Black 1934). Total $\mathrm{N}$ was determined using the micro-Kjeldahl approach, exchangeable phosphorus $(\mathrm{P})$ and available potassium $(\mathrm{K})$ was determined by (Jackson 1958).

\section{Statistical analysis}

The abundance data were statistically analyzed for mean, standard deviation, correlation, ANOVA and t-test using Microsoft Office, 2007.

\section{Result}

\section{Floral diversity}

A total of 223 species of vascular plants (angiosperm, gymnosperm and pteridophytes) were identified within the study area. These species belong to 57 families and 165 genera. Of these, 46 families and 151 genera belonging to angiosperm, 4 families and 5 genera of gymnosperms and 7 families and 9 genera of pteridophytes were found at both study sites between $3000-3600 \mathrm{~m}$ asl. Among the flowering plants (angiosperms and gymnosperms), the percent proportion of the life forms recorded as $4.6 \%$ trees, $18.77 \%$ shrubs and remaining $76.63 \%$ were herbs and forbs. Rosacaeae $(17.69 \%)$ family was exhibited dominant followed by Asteraceae (14.97\%), Ranunculaceae (12.93\%), Lamiaceae and Poaceae (7.48\% each). (Table 1). 
Table 1

Distribution of families in study areas

\begin{tabular}{|c|c|c|c|c|c|c|c|}
\hline \multirow[t]{2}{*}{ Families } & \multicolumn{2}{|c|}{ No. of genera } & \multicolumn{2}{|c|}{ No. of species } & \multicolumn{2}{|l|}{ Species \% } & \multirow{2}{*}{$\begin{array}{l}\text { Total } \\
\text { species } \\
\text { occurrence }\end{array}$} \\
\hline & $\begin{array}{l}\text { Ghangaria } \\
\text { Site }\end{array}$ & $\begin{array}{l}\text { Tolma } \\
\text { Site }\end{array}$ & $\begin{array}{l}\text { Ghangaria } \\
\text { Site }\end{array}$ & $\begin{array}{l}\text { Tolma } \\
\text { Site }\end{array}$ & $\begin{array}{l}\text { Ghangaria } \\
\text { Site }\end{array}$ & $\begin{array}{l}\text { Tolma } \\
\text { Site }\end{array}$ & \\
\hline \multicolumn{8}{|l|}{ Angiosperms } \\
\hline Ranunculaceae & 6 & 3 & 9 & 10 & 6.12 & 6.80 & 12.93 \\
\hline Berberidaceae & 1 & 1 & 3 & 2 & 2.04 & 1.36 & 3.40 \\
\hline Podophyllaceae & 1 & 1 & 1 & 1 & 0.68 & 0.68 & 1.36 \\
\hline Papaveraceae & 1 & 1 & 1 & 1 & 0.68 & 0.68 & 1.36 \\
\hline Brassicaceae & 1 & 1 & 1 & 2 & 0.68 & 1.36 & 2.04 \\
\hline Violaceae & 1 & 1 & 1 & 1 & 0.68 & 0.68 & 1.36 \\
\hline Polyglaceae & 1 & 1 & 1 & 1 & 0.68 & 0.68 & 1.36 \\
\hline Caryophyllaceae & 1 & 2 & 1 & 4 & 0.68 & 2.72 & 3.40 \\
\hline Geraniaceae & 1 & 0 & 3 & 0 & 2.04 & 0.00 & 2.04 \\
\hline Balsaminaceae & 1 & 0 & 2 & 0 & 1.36 & 0.00 & 1.36 \\
\hline Aceracear & 1 & 1 & 2 & 1 & 1.36 & 0.68 & 2.04 \\
\hline Fabaceae & 2 & 3 & 5 & 3 & 3.40 & 2.04 & 5.44 \\
\hline Rosaceae & 5 & 6 & 16 & 10 & 10.88 & 6.80 & 17.69 \\
\hline Saxifragaceae & 2 & 1 & 4 & 2 & 2.72 & 1.36 & 4.08 \\
\hline Grossulariaceae & 0 & 1 & 0 & 4 & 0.00 & 2.72 & 2.72 \\
\hline Crassulaceae & 0 & 2 & 0 & 6 & 0.00 & 4.08 & 4.08 \\
\hline Onagraceae & 1 & 1 & 2 & 1 & 1.36 & 0.68 & 2.04 \\
\hline Apiaceae & 3 & 3 & 5 & 3 & 3.40 & 2.04 & 5.44 \\
\hline Caprifoliaceae & 0 & 2 & 0 & 2 & 0.00 & 1.36 & 1.36 \\
\hline Rubiaceae & 1 & 0 & 2 & 0 & 1.36 & 0.00 & 1.36 \\
\hline Valerianaceae & 1 & 1 & 1 & 1 & 0.68 & 0.68 & 1.36 \\
\hline Dipsacaceae & 0 & 1 & 0 & 2 & 0.00 & 1.36 & 1.36 \\
\hline Asteraceae & 8 & 6 & 13 & 9 & 8.84 & 6.12 & 14.97 \\
\hline Campanulaceae & 1 & 1 & 2 & 2 & 1.36 & 1.36 & 2.72 \\
\hline Ericaceae & 2 & 1 & 3 & 2 & 2.04 & 1.36 & 3.40 \\
\hline
\end{tabular}




\begin{tabular}{|c|c|c|c|c|c|c|c|}
\hline \multirow[t]{2}{*}{ Families } & \multicolumn{2}{|c|}{ No. of genera } & \multicolumn{2}{|c|}{ No. of species } & \multicolumn{2}{|l|}{ Species \% } & \multirow{2}{*}{$\begin{array}{l}\text { Total } \\
\text { species } \\
\text { occurrence }\end{array}$} \\
\hline & $\begin{array}{l}\text { Ghangaria } \\
\text { Site }\end{array}$ & $\begin{array}{l}\text { Tolma } \\
\text { Site }\end{array}$ & $\begin{array}{l}\text { Ghangaria } \\
\text { Site }\end{array}$ & $\begin{array}{l}\text { Tolma } \\
\text { Site }\end{array}$ & $\begin{array}{l}\text { Ghangaria } \\
\text { Site }\end{array}$ & $\begin{array}{l}\text { Tolma } \\
\text { Site }\end{array}$ & \\
\hline Primulacaeae & 1 & 1 & 3 & 3 & 2.04 & 2.04 & 4.08 \\
\hline Gentianaceae & 3 & 2 & 5 & 3 & 3.40 & 2.04 & 5.44 \\
\hline Boraginaceae & 2 & 2 & 2 & 2 & 1.36 & 1.36 & 2.72 \\
\hline Cuscutaceae & 0 & 1 & 0 & 1 & 0.00 & 0.68 & 0.68 \\
\hline Scrophulariaceae & 3 & 2 & 4 & 3 & 2.72 & 2.04 & 4.76 \\
\hline Lamiaceae & 5 & 4 & 5 & 6 & 3.40 & 4.08 & 7.48 \\
\hline Plantaginaceae & 0 & 1 & 0 & 1 & 0.00 & 0.68 & 0.68 \\
\hline Chenopodiaceae & 1 & 1 & 1 & 1 & 0.68 & 0.68 & 1.36 \\
\hline Polygonaceae & 2 & 2 & 4 & 6 & 2.72 & 4.08 & 6.80 \\
\hline Thymelaeaceae & 1 & 0 & 1 & 0 & 0.68 & 0.00 & 0.68 \\
\hline Euphorbiaceae & 1 & 1 & 1 & 1 & 0.68 & 0.68 & 1.36 \\
\hline Urticaceae & 0 & 1 & 0 & 2 & 0.00 & 1.36 & 1.36 \\
\hline Betulaceae & 1 & 1 & 1 & 1 & 0.68 & 0.68 & 1.36 \\
\hline Salicaceae & 2 & 1 & 4 & 2 & 2.72 & 1.36 & 4.08 \\
\hline Orchidaceae & 4 & 2 & 5 & 2 & 3.40 & 1.36 & 4.76 \\
\hline Alliaceae & 1 & 0 & 3 & 0 & 2.04 & 0.00 & 2.04 \\
\hline Liliaceae & 4 & 3 & 6 & 4 & 4.08 & 2.72 & 6.80 \\
\hline Juncaceae & 0 & 1 & 0 & 2 & 0.00 & 1.36 & 1.36 \\
\hline Araceae & 1 & 0 & 3 & 0 & 2.04 & 0.00 & 2.04 \\
\hline Cyperaceae & 1 & 0 & 3 & 0 & 2.04 & 0.00 & 2.04 \\
\hline Poaceae & 2 & 5 & 5 & 6 & 3.40 & 4.08 & 7.48 \\
\hline \multicolumn{8}{|l|}{ Gymnosperms } \\
\hline Ephedraceae & 1 & 1 & 1 & 2 & 0.68 & 1.36 & 2.04 \\
\hline Cupressaceae & 1 & 1 & 3 & 2 & 2.04 & 1.36 & 3.40 \\
\hline Taxaceae & 1 & 1 & 1 & 1 & 0.68 & 0.68 & 1.36 \\
\hline Pinaceae & 2 & 2 & 2 & 3 & 1.36 & 2.04 & 3.40 \\
\hline
\end{tabular}




\begin{tabular}{|llllllll|}
\hline Families & \multicolumn{2}{l}{ No. of genera } & \multicolumn{2}{l}{ No. of species } & \multicolumn{2}{l|}{ Species \% } & \multicolumn{2}{l|}{$\begin{array}{l}\text { Total } \\
\text { species } \\
\text { occurrence }\end{array}$} \\
\cline { 2 - 5 } & $\begin{array}{l}\text { Ghangaria } \\
\text { Site }\end{array}$ & $\begin{array}{l}\text { Tolma } \\
\text { Site }\end{array}$ & $\begin{array}{l}\text { Ghangaria } \\
\text { Site }\end{array}$ & $\begin{array}{l}\text { Tolma } \\
\text { Site }\end{array}$ & $\begin{array}{l}\text { Ghangaria } \\
\text { Site }\end{array}$ & $\begin{array}{l}\text { Tolma } \\
\text { Site }\end{array}$ & \\
\hline Osmundaceae & 1 & 1 & 1 & 1 & 0.68 & 0.68 & 1.36 \\
\hline Polypodiaceae & 2 & 3 & 2 & 3 & 1.36 & 2.04 & 3.40 \\
\hline Cryptogrammaceae & 1 & 1 & 2 & 1 & 1.36 & 0.68 & 2.04 \\
\hline Adiantaceae & 1 & 1 & 1 & 1 & 0.68 & 0.68 & 1.36 \\
\hline Aspleniaceae & 0 & 1 & 0 & 2 & 0.00 & 1.36 & 1.36 \\
\hline Athyriaceae & 0 & 2 & 0 & 2 & 0.00 & 1.36 & 1.36 \\
\hline Dryopteridaceae & 0 & 1 & 0 & 3 & 0.00 & 2.04 & 2.04 \\
\hline
\end{tabular}

\section{Species richness and diversity}

The total species richness (tree and shrub) was found higher in Ghangaria as compared to the Tolma site. Most of the tree and shrub species were common at both the sites thus, resulting $90 \%$ similarity in tree layer and $60 \%$ similarity in shrub layer. Diversity index values were obtained slightly higher at Ghangaria site (7.9) as compared to Tolma site (7.84). However, the concentration of dominance (CD) particularly for the tree, sapling \& seedling layer was found higher at Tolma site as compared to Ghangaria site, whereas, shrub layer showed higher CD at Ghangaria site (Table 2). 
Table 2

Diversity Index $\left(\mathrm{H}^{\prime}\right)$ and concentration of dominance $(\mathrm{CD})$ for tree, sapling, seedling and shrub in Ghangaria and Tolma forest area of NDBR.

\begin{tabular}{|c|c|c|c|c|}
\hline Site & Parameters & $\begin{array}{l}\text { Forest } \\
\text { strata }\end{array}$ & Diversity & Dominant tree species \\
\hline \multirow{10}{*}{$\begin{array}{l}\text { Ghangaria } \\
\text { site (GS) }\end{array}$} & \multirow[t]{5}{*}{$H^{\prime}$} & Tree & 1.93 & \multirow{10}{*}{$\begin{array}{l}\text { Betula utilis, Cedrus deodar, Abies pindow, Taxus } \\
\text { baccata, Acer caesium, Salix sikkimensis, } \\
\text { Rhododendron campanulatum }\end{array}$} \\
\hline & & Sapling & 1.99 & \\
\hline & & Seedling & 1.99 & \\
\hline & & Shrub & 1.99 & \\
\hline & & Total & 7.9 & \\
\hline & \multirow[t]{5}{*}{ CD } & Tree & 0.18 & \\
\hline & & Sapling & 0.16 & \\
\hline & & Seedling & 0.15 & \\
\hline & & Shrub & 0.17 & \\
\hline & & Total & 0.66 & \\
\hline \multirow{10}{*}{$\begin{array}{l}\text { Tolma site } \\
\text { (TS) }\end{array}$} & \multirow[t]{5}{*}{$H^{\prime}$} & Tree & 1.65 & \multirow{10}{*}{$\begin{array}{l}\text { Betula utilis, Abies pindrow, Pinus wallichiana, Salix } \\
\text { sikkimensis, Cedrus deodar, Populus ciliata, Picea } \\
\text { smithiana, Acer caesium }\end{array}$} \\
\hline & & Sapling & 1.87 & \\
\hline & & Seedling & 1.77 & \\
\hline & & Shrub & 2.55 & \\
\hline & & Total & 7.84 & \\
\hline & \multirow[t]{5}{*}{ CD } & Tree & 0.26 & \\
\hline & & Sapling & 0.2 & \\
\hline & & Seedling & 0.22 & \\
\hline & & Shrub & 0.08 & \\
\hline & & Total & 0.76 & \\
\hline
\end{tabular}

\section{Population structure}

The total tree density $\left(1632\right.$ trees ha-1) and total basal area $\left(67.39 \mathrm{~m}^{2} \mathrm{ha}^{-1}\right)$ was recorded higher in Tolma site as compared to the Ghangaria site. Among the total tree density maximum (724 trees ha $\left.{ }^{-1}\right)$ was recorded for Betula utilis with highest IVI (114.35) at the same site. The Cedrus deodara was found an important co-dominant tree species (IVI 63.43) at Ghangaria siteand Pinus wallichiana (IVI 70.84) and Abies pindrow (IVI 58.42) at Tolma site, respectively (Table 3). The higher seedling density was recorded for $R$. campanulatum (320 sapling ha- ${ }^{-1}$ ) followed by Betula utilis (232 sapling ha- ${ }^{-1}$ ) at Ghangaria site, while at 
Tolma site, higher density was found for Betula utilis (544 sapling ha ${ }^{-1}$ ) and Salix sikkimensis (268 sapling $\left.\mathrm{ha}^{-1}\right)$. Abies pindrow was another associate species exhibited higher sapling density at both sites (168 sapling ha ${ }^{-1}$ and 244 sapling ha ${ }^{-1}$ each site). In the seedling stratum, the maximum total density was recorded at Tolma site (2328 seedling ha ${ }^{-1}$ ) as compared to the Ghangaria site (2032 seedling ha ${ }^{-1}$ ). Among the species, higher seedling density was recorded for Betula utilis at both the sites (920 seedling ha-1 and 456 seedling ha ${ }^{-1}$ each site) followed by Rhododendron campanulatum (428 seedling ha ${ }^{-1}$ ) and Abies pindrow (364 seedling ha ${ }^{-1}$ ).(Table 5).

Table 3

Phytosociological parameters of tree species around timberline zone of NDBR.

\begin{tabular}{|c|c|c|c|c|c|c|}
\hline \multirow[t]{2}{*}{ Tree species } & \multicolumn{3}{|c|}{ Ghangaria site } & \multicolumn{3}{|l|}{ Tolma site } \\
\hline & $\begin{array}{l}\text { Density trees } \\
\mathrm{ha}^{-1}\end{array}$ & $\begin{array}{l}\text { TBC } \mathrm{m}^{2} \\
\mathrm{ha}^{-1}\end{array}$ & IVI & $\begin{array}{l}\text { Density trees } \\
\mathrm{ha}^{-1}\end{array}$ & $\begin{array}{l}\text { TBC m² } \\
\mathrm{ha}^{-1}\end{array}$ & IVI \\
\hline Betula utilis & 368 & 6.7 & 85.68 & 724 & 12.8 & 114.35 \\
\hline Abies pindrow & 128 & 4.8 & 48.70 & 248 & 41.3 & 58.42 \\
\hline Cedrus deodara & 156 & 8.5 & 63.43 & 44 & 0.45 & 7.20 \\
\hline Pinus wallichiana & - & - & - & 384 & 11.9 & 70.83 \\
\hline Taxus baccata & 132 & 3.2 & 38.93 & 60 & 0.19 & 11.51 \\
\hline Acer caesium & 80 & 0.1 & 22.64 & 20 & 0.04 & 5.84 \\
\hline Sorbus foliolosa & 36 & 0.2 & 10.23 & - & - & - \\
\hline $\begin{array}{l}\text { Rhododendron } \\
\text { campanulatum }\end{array}$ & 44 & 0.3 & 12.33 & - & - & - \\
\hline Salix sikkimensis & 20 & 0.3 & 5.690 & 68 & 0.2 & 12.63 \\
\hline Populus ciliata & - & - & - & 60 & 0.36 & 13.73 \\
\hline Picea smithiana & - & - & - & 24 & 0.11 & 5.44 \\
\hline Prunus cornuta & 52 & 1.0 & 12.33 & - & - & - \\
\hline Total & 10.16 & 25.18 & 300 & 16.32 & 67.39 & 300 \\
\hline
\end{tabular}

In the shrub layer Ribes alpestre (396 individuals ha ${ }^{-1}$ ), Origanum vulgure (332 individuals ha ${ }^{-1}$ ), Spiraea bella (224 individuals ha-1 ${ }^{-1}$ ), Polygonum polystachyum (176 individuals ha- ${ }^{-1}$ ), and Rosa webbiana (132 individuals ha-1) showed higher density at the Ghangaria site, while at Tolma, highest density was represented by Berberis jaschiana (228 individuals ha ${ }^{-1}$ ) followed by Salix sikkimensis (176 individuals $\mathrm{ha}^{-1}$ ), Indigofera heterantha (152 individuals ha ${ }^{-1}$ ) and Sorbus microphylla (120 individuals ha ${ }^{-1}$ ) (Table 4). In the herbaceous layer at Ghangaria site, the dominant species were found in following sequence Fragaria nubicola (844 individuals ha $\left.{ }^{-1}\right)>0$ Oxalis corniculata $\left(812\right.$ individuals ha $\left.{ }^{-1}\right)>$ Geranium wallichianum (780 
individuals ha $\left.{ }^{-1}\right)>$ Anaphalis triplinervis $\left(736\right.$ individuals ha $\left.{ }^{-1}\right)>$ Impatiens sulcata (364 individuals ha ${ }^{-1}$ ). The other co-dominant species were recorded includes Potentilla atrisanguinea, Fragaria nubicola, Anemone obtusifolia, Ligularia amplexicaulis, Origanum vulgare, Senecio graciliflorus, etc. However, Tolma site exhibited maximum density for Geranium himalayense ( 1384 individuals $\mathrm{ha}^{-1}$ ), followed by Oxalis corcunata (792 individuals ha ${ }^{-1}$ ) and Fragaria nubicola (756 individuals ha ${ }^{-1}$ ) and minimum was found for Angelica glauca (48 individuals ha- ${ }^{-1}$ ), Bergenia ciliata (112 individuals ha ${ }^{-1}$ ), and Malaxis muscifera (140 individuals $\left.\mathrm{ha}^{-1}\right)$. Some other important associated prominent species found in the area were Berginia starchy, Bistorta affinis, Geum elatum, Impatiens devendrae, Taraxacum officinale, Origanum vulgare etc. 
Table 4

Phytosociological parameters of shrub species around timberline zone of NDBR.

\begin{tabular}{|c|c|c|c|c|c|c|}
\hline \multirow[t]{3}{*}{ Species } & \multicolumn{3}{|l|}{ Ghangaria site } & \multicolumn{3}{|c|}{ Tolma site } \\
\hline & Density Ind. ha ${ }^{-1}$ & A/F ratio & IVI & Density & AVF ratio & IVI \\
\hline & & & & Ind. $\mathrm{ha}^{-1}$ & & \\
\hline Astragalus chlorostachys & - & - & - & 108 & 0.421 & 11.96 \\
\hline Berberis aristata & - & - & - & 60 & 0.234 & 8.81 \\
\hline Berberis jaeschkeana & 72 & 0.18 & 14.36 & 228 & 0.291 & 23.49 \\
\hline Colquhounia coccinea & - & - & - & 88 & 0.22 & 11.87 \\
\hline Elsholtzia fruticosa & - & - & - & 88 & 0.22 & 11.87 \\
\hline Fren spp & 80 & 1.25 & 9.5 & - & - & - \\
\hline Indigofera heterantha & - & - & - & 152 & 0.38 & 16.07 \\
\hline Lonicera microphylla & 64 & 0.44 & 10.15 & - & - & - \\
\hline Origanum vulgure & 332 & 0.32 & 38.88 & - & - & - \\
\hline Prinspia utilis & 64 & 0.25 & 11.96 & 88 & 0.22 & 11.87 \\
\hline Polygonum polystachyum & 176 & 0.13 & 22.64 & - & - & - \\
\hline Ribies alpester & 396 & 0.31 & 35.39 & 92 & 0.159 & 13.35 \\
\hline Rosa microphylla & 80 & 0.1 & 14.59 & 112 & 0.143 & 15.886 \\
\hline Rosa webbiana & 132 & 0.23 & 14.58 & - & - & - \\
\hline Rosa serica & - & - & - & 80 & 0.139 & 12.56 \\
\hline Rubus niveus & - & - & - & 56 & 0.072 & 12.21 \\
\hline Sorbus microphylla & 112 & 0.14 & 11.94 & 120 & 0.092 & 18.84 \\
\hline Sorbaria tomentosa & 32 & 0.13 & 9.62 & 76 & 0.132 & 12.30 \\
\hline Spiraea bella & 224 & 0.22 & 7.46 & - & - & - \\
\hline salix lindleyana & - & - & - & 176 & 0.306 & 18.86 \\
\hline Total & 1364 & 3.35 & 200 & 1524 & 3.029 & 200 \\
\hline
\end{tabular}

\section{Regeneration potential}

In all 12 tree species were found along an elevational gradient between $3000-3600 \mathrm{~m}$ asl at both buffer areas of NDBR. Among all these tree species, $56 \%$ showed fair regeneration, $22 \%$ showed good regeneration, $11 \%$ exhibited poor and remaining (11\%) indicated no regeneration at Ghangaria site; while at Tolma site, 
$40 \%$ species showed fair regeneration, $40 \%$ had good regeneration and remaining $20 \%$ exhibited no regeneration. In Ghangaria site two species viz., Salix sikkimensis and Rhododendron campanulatum showed good regeneration as both the species represented by good number of seedlings and saplings. However, about 5 plant species showed fair regeneration those includes Betula utilis, Abies pindrow, Taxus baccata, Cedrus deodara and Sorbus tomentosa, whereas species such as Acer caesium showed poor regeneration and Prunus cornuta exhibited no regenerating. In Tolma forest site, about 4 species (viz., Salix sikkimensis, Populus ciliata, Taxus baccata and Cedus deodara) showed good regeneration (Table 5).

Table 5

Regeneration status (density ha ${ }^{-1}$ ) of trees species around Ghangaria and Tolma sites, NDBR.

\begin{tabular}{|c|c|c|c|c|c|c|c|c|}
\hline \multirow{2}{*}{$\begin{array}{l}\text { Dominant tree } \\
\text { species }\end{array}$} & \multicolumn{4}{|c|}{ Ghangaria site } & \multicolumn{4}{|c|}{ Tolma site } \\
\hline & Tree & Sapling & Seedling & Status & Tree & Sapling & Seedling & Status \\
\hline Betula utilis & 484 & 232 & 456 & $\mathrm{~F}$ & 852 & 544 & 920 & $\mathrm{~F}$ \\
\hline Abies pindrow & 192 & 168 & 340 & $\mathrm{~F}$ & 392 & 244 & 364 & $\mathrm{~F}$ \\
\hline Salix sikkimensis & 76 & 148 & 196 & G & 68 & 268 & 344 & G \\
\hline Pinus wallichiana & - & - & - & SA & 464 & 100 & 200 & $\mathrm{~F}$ \\
\hline Acer caesium & 80 & 156 & 104 & $P$ & 20 & 68 & - & NR \\
\hline Populus ciliata & - & - & - & SA & 60 & 80 & 100 & G \\
\hline Taxus baccata & 196 & 164 & 300 & $\mathrm{~F}$ & 60 & 68 & 176 & G \\
\hline Picea smithiana & - & - & - & SA & 24 & - & - & NR \\
\hline Cedus deodara & 180 & 60 & 100 & $\mathrm{~F}$ & 44 & 96 & 104 & G \\
\hline $\begin{array}{l}\text { Rhododendron } \\
\text { campanulatum }\end{array}$ & 172 & 320 & 428 & G & 108 & 56 & 120 & $\mathrm{~F}$ \\
\hline Sorbus tomentosa & 36 & 140 & 108 & $\mathrm{~F}$ & - & - & - & SA \\
\hline Prunus cornuta & 52 & - & - & NR & - & - & - & SA \\
\hline Total & 1468 & 1388 & 2032 & & 2092 & 1524 & 2328 & \\
\hline
\end{tabular}

\section{Soil characteristics}

Soil water holding capacity $(49.94 \pm 5.63)$ and moisture content $(60.43 \pm 9.71)$ was found higher in $\mathrm{N}$-aspect as compared to S-aspect at Tolma site. However, Ghangaria site also exhibit higher WHC (33.50 \pm 4.54$)$ for Naspect while soil moisture showed maximum $(63.77 \pm 4.77)$ in S-aspect. Tolma site revealed maximum bulk density for S-aspect $(0.91 \pm 0.10)$ as compared to $\mathrm{N}$-aspect while Ghangaria site ranged between $1.03 \mathrm{~g} \mathrm{~cm}^{3}$ to $1.06 \mathrm{gcm}^{3}$ in $\mathrm{S}$ and $\mathrm{N}$-aspect, respectively. As far as soil structure concerned sand was the prime 
constituent of the soil in both aspect and sites, however decreasing trend was observed in silt proportion with increasing altitudinal. The soil pH ranged between 6.54 to 6.77 and 6.28 to 6.94 in Tolma and Ghangaria site, respectively. The availability of phosphorus $(0.11 \pm 0.01)$, potassium (1.32 \pm 0.56$)$, total organic carbon ( 1.04 $\pm 0.30)$ and organic matter $(1.79 \pm 0.52)$ was found maximum in S-aspect whereas nitrogen concentration $(0.170 \pm 0.07)$ recorded higher at $\mathrm{N}$-aspect of Tolma site, whereas phosphorus concentration revealed almost similar value $(0.09 \pm 0.01)$ for both aspect while the potassium $(1.33 \pm 0.27)$ was recorded higher in $\mathrm{N}$ aspect. The total nitrogen value $(0.218 \pm 0.06)$, total organic carbon $(1.06 \pm 0.25)$ and organic matter $(1.82 \pm 0.44)$ showed highest in S-aspect at Ghangaria site.

\section{Statistical analysis}

The species richness was observed decreased with increasing elevational gradient showed significant relationship $\left(R^{2}=0.826, p<0.003\right)$, whereas Simpson's Index of Dominance and the altitude demonstrates a positive quadrate relation $\left(R^{2}=0.326, p<0.066\right)$. Both forest sites, revealing declining trend among the Shannone Weiner Diversity Index $\left(R^{2}=0.434, p<0.026\right)$ and the Shannon Index of species evenness $\left(R^{2}=\right.$ $0.243, p<0.069)$ with the increasing altitudinal gradient.

\section{Discussion}

The community structure and regeneration status of the plant species could be predicted from the relative proportion of seedlings, saplings and adults in the total populations of different species. The present study exhibit the regeneration of the dominant species was quite moderate except for the Betula utilis and Rhododendron campanulatum. The higher seedling and sapling density of Betula utilis along the timberline is predicted better growth, survival and the advancement, but negligible in the near settlement and highly disturb area (Rai et al. 2012). The population structure of the forest in the present study reveals that dominant species of the buffer zone of NDBR are distributed in all the life stage classes. However, the percentage density declines progressively from seedling to adult tree stages along the altitudinal gradient up to the upper timberline. Among the plant species, Betula utilis had highest tree density ( $724 \& 324$ trees ha $\left.^{-1}\right)$, contributed $44 \%$ and $36 \%$ of the total population at Tolma and Ghangaria sites followed by Pinus wallichiana (24\%) and Cedrus deodara (15\%), respectively. The average total basal area was recorded $2.77 \mathrm{~m}^{2} \mathrm{ha}^{-1}$ at Ghangaria and $7.48 \mathrm{~m}^{2} \mathrm{ha}^{-1}$ at Tolma site. The study also reveals that shrubs and herbs density was found higher in the Ghangaria site where anthropogenic disturbance was lower than Tolma site of buffer zone. Besides, both the study areas showed a good number of seedling and sapling population. Among the tree species, higher density was represented by Betula utilis at both the sites with maximum density (2476 trees ha-1) were recorded at Tolma site and lower for Vibernum spp (100 trees ha-1 ${ }^{-1}$ followed by Prunus cornuta (50 trees ha-1 ${ }^{-1}$. Some species viz., Populus ciliata, Picea smithiana and Pinus wallichiana were not found at Ghangaria site but present at Tolma site (Table 1). Regeneration of both forests sites although showed progressive, but it was found better in Tolma site because of high density of seedlings and saplings. Human presence for pilgrimage and nature tourism and livestock grazing, along with cutting, lopping, and debarking of trees and extraction of other bio-resources such as medicinal plants which might have affected the regeneration of species at Ghangaria site. 
The present study showed huge variation in the density, basal area and species diversity in temperate forest ecosystem due to the topography, altitudinal variation, forest type and micro climatic conditions (Table 6.). The species richness reported in the present study higher and nearby than result observed (species $=75$; tree $=3$; shrub $=12$; herb $=60$ ) from Kedarnath wildlife sanctuary, Western Himalaya, Uttarakhand (Rai et al. 2012); in temperate forest of Dudhatoli Garhwal Himalaya (species 268); in temperate forest of Azad Kashmir (species 200) and Naran Valley of Pakistan (species 198). However, the species richness value lower than the moist temperate forest of Mandal-Chopta (species 300), Garhwal Himalaya, Uttarakhand (Gairola et al. 2010) and in temperate forest NDBR (species 451), Western Himalaya, India (Rawat et al. 2015). Rosaceae (17.69) \%), Asteraceae (14.97\%), Ranunculaceae (12.93\%), Lamiaceae and Poaceae (7.48 each), Liliaceae and Polygonaceae (6.80 each) were the most dominant species families in temperate forests of Western Himalaya. Similarly, Asteraceae and Lamiaceae have been reported as dominant families in temperate forests of India and elsewhere (Gairola et al., 2010, Saima et al., 2010, Khan et al., 2012, Sharma et al., 2013). Shaheen et al (2011a) also reported that Asteraceae (19\%), Poaceae (13\%), Ranunculaceae (11\%), Rosaceae (8\%), and Saxifragaceae (8\%) were dominant families in western Himalayas, northern Pakistan. Dar et al (2012) also reported Asteraceae (260 species), Poaceae (160 species), Brassicaceae (115 species), Rosaceae (98 species), and Lamiaceae (88 species) were the major species families in Kashmir Himalaya. Hooker (1906) stated Orchidaceae, Fabaceae, Poaceae, Rubiaceae, Euphorbiaceae, Acanthaceae, Asteraceae, Cyperaceae, Lamiaceae, and Utricaceae as the diverse families of India. Therefore, the result of study also explicit that across various temperate forests of the world having a close similarity is an evident at the families' level. Maximum shrub density was recorded for Ribies alpester and Berberis jaeschkeana while minimum observed for Sorbaria tomentosa and Rubus niveus in Ghangaria and Tolma site, respectively. The dominant herbaceous species followed the sequence i.e., Fragaria nubicola $>0 x a l i s$ corniculata $>$ Geranium wallichianum > Anaphalis triplinervis > Impatiens sulcata in Ghangaria site. However, Geranium himalayense was recorded dominant species with Oxalis corniculata and Fragaria nubicola as co-dominant species at Tolma site. 
Table 6

Comparisons of phytosociological attributes and species richness of different temperate forest of the present and previous study.

\begin{tabular}{|c|c|c|c|c|c|c|c|}
\hline Forest type & Region/locality & $\begin{array}{l}\text { Elevation } \\
\text { (m. asl.) }\end{array}$ & $\begin{array}{l}\text { Total } \\
\text { area } \\
\text { sampled }\end{array}$ & $\begin{array}{l}\text { Density } \\
\text { (D) }\end{array}$ & $\begin{array}{l}\text { Basal } \\
\text { Area } \\
\text { (BA) }\end{array}$ & $\begin{array}{l}\text { Species } \\
\text { richness }\end{array}$ & Source \\
\hline $\begin{array}{l}\text { Temperate } \\
\text { forests }\end{array}$ & $\begin{array}{l}\text { Kashmir } \\
\text { Himalaya, India }\end{array}$ & $\begin{array}{l}1,550- \\
3,250\end{array}$ & $\begin{array}{l}111 \\
\text { (.25 ha) }\end{array}$ & $\begin{array}{l}103- \\
1,201\end{array}$ & $\begin{array}{l}19.4- \\
51.9\end{array}$ & $\begin{array}{l}177= \\
14 \mathrm{~T}+ \\
17 \mathrm{~S}+ \\
146 \mathrm{H}\end{array}$ & $\begin{array}{l}\text { Dar et al. } \\
2016\end{array}$ \\
\hline $\begin{array}{l}\text { Temperate } \\
\text { forests }\end{array}$ & $\begin{array}{l}\text { Changbai } \\
\text { Mountains, } \\
\text { China }\end{array}$ & $\begin{array}{l}750- \\
2,100\end{array}$ & $\begin{array}{l}68 \\
(0.04 \mathrm{ha})\end{array}$ & - & - & $\begin{array}{l}213= \\
37^{\top}+ \\
32^{S}+ \\
144^{H}\end{array}$ & $\begin{array}{l}\text { Bai et al. } \\
2011\end{array}$ \\
\hline $\begin{array}{l}\text { Sub-alpine } \\
\text { region }\end{array}$ & $\begin{array}{l}\text { Garhwal } \\
\text { Himalaya, India }\end{array}$ & $\begin{array}{l}2,200- \\
3,000\end{array}$ & $\begin{array}{l}20(50 \times \\
50 \mathrm{~m}) \\
50 \mathrm{ha}\end{array}$ & - & - & 90 & $\begin{array}{l}\text { Bisht and } \\
\text { Bhat } 2013\end{array}$ \\
\hline $\begin{array}{l}\text { Temperate } \\
\text { Deciduous } \\
\text { forest }\end{array}$ & Denmark & - & 50 ha & 770 & 30.7 & 165 & $\begin{array}{l}\text { Borchsenius } \\
\text { et al. } 2004\end{array}$ \\
\hline $\begin{array}{l}\text { Sub } \\
\text { tropical to } \\
\text { warm } \\
\text { temperate }\end{array}$ & $\begin{array}{l}\text { Central } \\
\text { Himalaya }\end{array}$ & $\begin{array}{l}1,300- \\
1,750\end{array}$ & $\begin{array}{l}40 \\
\text { (0.01 ha) }\end{array}$ & $\begin{array}{l}540- \\
1630\end{array}$ & $\begin{array}{l}25- \\
47.2\end{array}$ & - & $\begin{array}{l}\text { Chaturvedi } \\
\text { \& Singh } \\
1987\end{array}$ \\
\hline \multirow{2}{*}{$\begin{array}{l}\text { Tropical } \\
\text { semi } \\
\text { evergreen }\end{array}$} & \multirow{2}{*}{$\begin{array}{l}\text { Manipur } \\
\text { Northeast, } \\
\text { India }\end{array}$} & \multirow[t]{2}{*}{-} & \multirow{2}{*}{$\begin{array}{l}20 \\
\text { (0.01 ha } \\
\text { each) }\end{array}$} & \multirow[t]{2}{*}{$\begin{array}{l}10- \\
675\end{array}$} & \multirow[t]{2}{*}{ - } & $\begin{array}{l}123= \\
17^{\top}+\end{array}$ & $\begin{array}{l}\text { Devi and } \\
\text { Yadava }\end{array}$ \\
\hline & & & & & & $\begin{array}{l}36^{\mathrm{S}}+ \\
70^{\mathrm{H}}\end{array}$ & 2006 \\
\hline $\begin{array}{l}\text { Abies } \\
\text { pindow }\end{array}$ & $\begin{array}{l}\text { Pithoragarh, } \\
\text { Kumaun } \\
\text { Himalaya }\end{array}$ & 3100 & $\begin{array}{l}3 \\
(0.5 \mathrm{ha})\end{array}$ & 660 & 78.90 & - & $\begin{array}{l}\text { Dhar et al. } \\
1997\end{array}$ \\
\hline $\begin{array}{l}\text { Moist } \\
\text { temperate } \\
\text { forest }\end{array}$ & $\begin{array}{l}\text { Mandal- } \\
\text { CHopta, } \\
\text { Garhwal } \\
\text { Himalaya, } \\
\text { Uttarakhand, } \\
\text { India }\end{array}$ & $\begin{array}{l}1500- \\
3000\end{array}$ & NA & - & - & 338 & $\begin{array}{l}\text { Gairola et } \\
\text { al. } 2010\end{array}$ \\
\hline $\begin{array}{l}\text { Moist } \\
\text { temperate } \\
\text { forest }\end{array}$ & $\begin{array}{l}\text { Western } \\
\text { Himalaya } \\
\text { Garhwal, } \\
\text { Uttarakhand } \\
\text { India }\end{array}$ & $\begin{array}{l}2400- \\
2850\end{array}$ & NA & $\begin{array}{l}380- \\
1,180\end{array}$ & $\begin{array}{l}41.25- \\
86.56\end{array}$ & 65 & $\begin{array}{l}\text { Gairola et } \\
\text { al. 2011a }\end{array}$ \\
\hline $\begin{array}{l}\text { Moist } \\
\text { temperate } \\
\text { forest }\end{array}$ & $\begin{array}{l}\text { Western } \\
\text { Himalaya, India }\end{array}$ & $\begin{array}{l}1500- \\
2500\end{array}$ & NA & $\begin{array}{l}990- \\
1,470\end{array}$ & $\begin{array}{l}35.08- \\
84.25\end{array}$ & 125 & $\begin{array}{l}\text { Gairola et } \\
\text { al. } 2011 \mathrm{~b}\end{array}$ \\
\hline
\end{tabular}




\begin{tabular}{|c|c|c|c|c|c|c|c|}
\hline Forest type & Region/locality & $\begin{array}{l}\text { Elevation } \\
\text { (m. asl.) }\end{array}$ & $\begin{array}{l}\text { Total } \\
\text { area } \\
\text { sampled }\end{array}$ & $\begin{array}{l}\text { Density } \\
\text { (D) }\end{array}$ & $\begin{array}{l}\text { Basal } \\
\text { Area } \\
\text { (BA) }\end{array}$ & $\begin{array}{l}\text { Species } \\
\text { richness }\end{array}$ & Source \\
\hline $\begin{array}{l}\text { Temperate } \\
\text { forest }\end{array}$ & $\begin{array}{l}\text { Mandal- } \\
\text { CHopta, } \\
\text { Garhwal } \\
\text { Himalaya, } \\
\text { Uttarakhand, } \\
\text { India }\end{array}$ & $\begin{array}{l}1,500- \\
2,850\end{array}$ & NA & $\begin{array}{l}380- \\
1,390\end{array}$ & $\begin{array}{l}32.77- \\
86.56\end{array}$ & - & $\begin{array}{l}\text { Gairola et } \\
\text { al. } 2012\end{array}$ \\
\hline $\begin{array}{l}\text { Temperate } \\
\text { forest }\end{array}$ & $\begin{array}{l}\text { Northeast } \\
\text { Spain }\end{array}$ & $\begin{array}{l}1500- \\
2200\end{array}$ & 329 & - & - & 9 & $\begin{array}{l}\text { Gracia et al. } \\
2007\end{array}$ \\
\hline Dry forest & $\begin{array}{l}\text { Miombo, } \\
\text { Zambia }\end{array}$ & $\begin{array}{l}1,292- \\
1300\end{array}$ & $\begin{array}{l}24 \\
(0.25 \mathrm{ha})\end{array}$ & $\begin{array}{l}308- \\
736\end{array}$ & $\begin{array}{l}5.6- \\
27.5\end{array}$ & 83 & $\begin{array}{l}\text { Kalaba et al } \\
2013\end{array}$ \\
\hline $\begin{array}{l}\text { Temperate } \\
\text { forest }\end{array}$ & $\begin{array}{l}\text { Naran Valley, } \\
\text { Pakistan }\end{array}$ & $\begin{array}{l}2,450- \\
4100\end{array}$ & $\begin{array}{l}144 \\
(0.25 \mathrm{ha})\end{array}$ & - & - & $\begin{array}{l}198= \\
12^{\top}+ \\
20^{S}+ \\
166^{H}\end{array}$ & $\begin{array}{l}\text { Khan et al. } \\
2011\end{array}$ \\
\hline $\begin{array}{l}\text { Community } \\
\text { temperate } \\
\text { forest }\end{array}$ & $\begin{array}{l}\text { Dolpha Mid- } \\
\text { west, Nepal }\end{array}$ & $\begin{array}{l}1,900- \\
2700\end{array}$ & $\begin{array}{l}20 \\
(0.01 \mathrm{ha})\end{array}$ & $\begin{array}{l}2,090- \\
2100\end{array}$ & $\begin{array}{l}90.07- \\
151.98\end{array}$ & 98 & $\begin{array}{l}\text { Kunwar \& } \\
\text { Sharma } \\
2004\end{array}$ \\
\hline $\begin{array}{l}\text { Temperate } \\
\text { forest }\end{array}$ & $\begin{array}{l}\text { Manang, } \\
\text { Central Nepal }\end{array}$ & $\begin{array}{l}3,000- \\
4,000\end{array}$ & $\begin{array}{l}80 \\
(0.01 \mathrm{ha})\end{array}$ & - & - & 168 & $\begin{array}{l}\text { Panthi et } \\
\text { al.2007 }\end{array}$ \\
\hline $\begin{array}{l}\text { Temperate } \\
\text { forest }\end{array}$ & $\begin{array}{l}\text { Arunachal } \\
\text { Pradesh, India }\end{array}$ & $350-700$ & $\begin{array}{l}60 \\
(0.01 \mathrm{ha})\end{array}$ & $\begin{array}{l}550- \\
860\end{array}$ & $\begin{array}{l}19.61- \\
78.32\end{array}$ & $\begin{array}{l}128= \\
41^{\top}+ \\
22^{S}+ \\
65^{H}\end{array}$ & $\begin{array}{l}\text { Rana and } \\
\text { Gairola } \\
2009\end{array}$ \\
\hline $\begin{array}{l}\text { Temperate } \\
\text { forest }\end{array}$ & $\begin{array}{l}\text { Garhwal } \\
\text { Himalaya, India }\end{array}$ & $\begin{array}{l}500- \\
6940\end{array}$ & $\begin{array}{l}20 \\
(0.01 \text { ha })\end{array}$ & $\begin{array}{l}1,090- \\
1980\end{array}$ & $\begin{array}{l}20.97- \\
40.19\end{array}$ & $8-19$ & Raturi 2012 \\
\hline $\begin{array}{l}\text { Wet } \\
\text { temperate } \\
\text { forest }\end{array}$ & $\begin{array}{l}\text { Abottabad, } \\
\text { Pakistan }\end{array}$ & $\begin{array}{l}800- \\
2500\end{array}$ & NA & - & - & 167 & $\begin{array}{l}\text { Saima et al. } \\
2010\end{array}$ \\
\hline $\begin{array}{l}\text { Temperate } \\
\text { forest }\end{array}$ & $\begin{array}{l}\text { Kumaun } \\
\text { Himalaya }\end{array}$ & $\begin{array}{l}1280- \\
2227\end{array}$ & $\begin{array}{l}48 \\
\text { (0.01 ha) }\end{array}$ & - & - & $7-21$ & $\begin{array}{l}\text { Saxena \& } \\
\text { Singh } 1984\end{array}$ \\
\hline $\begin{array}{l}\text { Temperate } \\
\text { forest }\end{array}$ & $\begin{array}{l}\text { Central } \\
\text { Himalaya, India }\end{array}$ & $\begin{array}{l}1400- \\
2700\end{array}$ & $\begin{array}{l}60 \\
(0.01 \mathrm{ha})\end{array}$ & $\begin{array}{l}20- \\
170\end{array}$ & - & $\begin{array}{l}116= \\
16^{\top}+ \\
35^{\mathrm{S}}+ \\
65^{\mathrm{H}}\end{array}$ & $\begin{array}{l}\text { Semwal et } \\
\text { al.2010 }\end{array}$ \\
\hline $\begin{array}{l}\text { Temperate } \\
\text { forest }\end{array}$ & $\begin{array}{l}\text { Western } \\
\text { Himalaya, } \\
\text { northen } \\
\text { Pakistan }\end{array}$ & $>3300$ & $\begin{array}{l}30 \\
(0.01 \mathrm{ha})\end{array}$ & - & - & 83 & $\begin{array}{l}\text { Shaheen et } \\
\text { al. 2011a }\end{array}$ \\
\hline $\begin{array}{l}\text { Temperate } \\
\text { alpine } \\
\text { pasture }\end{array}$ & $\begin{array}{l}\text { Western } \\
\text { Himalaya, } \\
\text { Pakistan }\end{array}$ & $\begin{array}{l}2600- \\
3500\end{array}$ & 20.5 ha & - & - & 69 & $\begin{array}{l}\text { Shaheen et } \\
\text { al. 2011b }\end{array}$ \\
\hline
\end{tabular}




\begin{tabular}{|c|c|c|c|c|c|c|c|}
\hline Forest type & Region/locality & $\begin{array}{l}\text { Elevation } \\
\text { (m. asl.) }\end{array}$ & $\begin{array}{l}\text { Total } \\
\text { area } \\
\text { sampled }\end{array}$ & $\begin{array}{l}\text { Density } \\
\text { (D) }\end{array}$ & $\begin{array}{l}\text { Basal } \\
\text { Area } \\
\text { (BA) }\end{array}$ & $\begin{array}{l}\text { Species } \\
\text { richness }\end{array}$ & Source \\
\hline $\begin{array}{l}\text { Moist } \\
\text { temperate } \\
\text { forest }\end{array}$ & $\begin{array}{l}\text { Western } \\
\text { Himalaya, } \\
\text { Kashmir }\end{array}$ & $\begin{array}{l}1700- \\
2600\end{array}$ & $\begin{array}{l}180 \\
\text { (900 m2 } \\
\text { each) }\end{array}$ & $\begin{array}{l}90- \\
227\end{array}$ & $\begin{array}{l}42.32- \\
105.29\end{array}$ & 122 & $\begin{array}{l}\text { Shaheen et } \\
\text { al. } 2012\end{array}$ \\
\hline $\begin{array}{l}\text { Moist } \\
\text { temperate } \\
\text { forest }\end{array}$ & $\begin{array}{l}\text { Dudhatoli } \\
\text { Garhwal } \\
\text { Himalaya }\end{array}$ & $\begin{array}{l}1800- \\
3000\end{array}$ & NA & - & - & 268 & $\begin{array}{l}\text { Sharma et } \\
\text { al. } 2013\end{array}$ \\
\hline Alpine zone & $\begin{array}{l}\text { Northwest } \\
\text { Yunnan, China }\end{array}$ & $\begin{array}{l}3800- \\
5200\end{array}$ & $\begin{array}{l}70 \\
(0.036)\end{array}$ & - & - & 369 & $\begin{array}{l}\text { Sherman et } \\
\text { al. } 2012\end{array}$ \\
\hline $\begin{array}{l}\text { Temperate } \\
\text { forest }\end{array}$ & $\begin{array}{l}\text { Shimla, } \\
\text { Himachal } \\
\text { Pradesh, India }\end{array}$ & $\begin{array}{l}1650- \\
2295\end{array}$ & $\begin{array}{l}36 \\
\text { (0.01 ha) }\end{array}$ & $\begin{array}{l}4,217- \\
7765\end{array}$ & $\begin{array}{l}18.49- \\
52.54\end{array}$ & $\begin{array}{l}55=6^{\top} \\
+14^{\mathrm{S}}+ \\
35^{\mathrm{H}}\end{array}$ & $\begin{array}{l}\text { Singh \& } \\
\text { Gupta } 2009\end{array}$ \\
\hline $\begin{array}{l}\text { Temperate: } \\
\text { Evergreen } \\
\text { deciduous } \\
\& \\
\text { coniferous }\end{array}$ & $\begin{array}{l}\text { Mt.Emei, } \\
\text { Sichuen, China }\end{array}$ & $\begin{array}{l}680- \\
3099\end{array}$ & $\begin{array}{l}10 \\
(0.02- \\
0.04)\end{array}$ & - & - & 122 & $\begin{array}{l}\text { Tang \& } \\
\text { Ohsawa } \\
1997\end{array}$ \\
\hline $\begin{array}{l}\text { Temperate } \\
\text { forest }\end{array}$ & $\begin{array}{l}\text { Azad Kashmir, } \\
\text { Pakistan }\end{array}$ & - & $\begin{array}{l}70 \\
(0.01 \mathrm{ha})\end{array}$ & - & - & 200 & $\begin{array}{l}\text { Tanvir et al. } \\
2014\end{array}$ \\
\hline $\begin{array}{l}\text { Temperate } \\
\text { forest }\end{array}$ & $\begin{array}{l}\text { Baihua } \\
\text { Mountain, } \\
\text { China }\end{array}$ & $\begin{array}{l}750- \\
2043\end{array}$ & $\begin{array}{l}61 \\
(0.02 \text { ha) }\end{array}$ & - & - & 71 & $\begin{array}{l}\text { Zhang et al. } \\
2013\end{array}$ \\
\hline
\end{tabular}


Table 7

Over all physiochemical properties of Tolma and Ghangaria sites.

\begin{tabular}{|lllll|}
\hline Parameter & \multicolumn{3}{l}{ Ghangaria site } & Tolma site \\
& N aspect & South aspect & N aspect & South aspect \\
\hline Sand (\%) & $63.98 \pm 8.27$ & $46.88 \pm 2.70$ & $60.11 \pm 4.13$ & $64.99 \pm 3.95$ \\
\hline Silt (\%) & $50.4 \pm 5.45$ & $34.65 \pm 2.71$ & $33.01 \pm 4.11$ & $27.20 \pm 3.16$ \\
\hline Clay (\%) & $0.88 \pm 0.06$ & $0.87 \pm 0.12$ & $6.88 \pm 2.80$ & $7.82 \pm 1.41$ \\
\hline Moisture (\%) & $57.41 \pm 3.27$ & $63.77 \pm 4.77$ & $60.43 \pm 9.71$ & $46.49 \pm 3.85$ \\
\hline WHC (\%) & $33.50 \pm 4.54$ & $28.70 \pm 3.35$ & $49.94 \pm 5.63$ & $40.58 \pm 6.91$ \\
\hline bD (g cm $\left.{ }^{-3}\right)$ & $1.06 \pm 1.71$ & $1.03 \pm 3.29$ & $0.85 \pm 0.13$ & $0.91 \pm 0.10$ \\
\hline pH & $6.94 \pm 0.15$ & $6.28 \pm 0.22$ & $6.77 \pm 0.30$ & $6.54 \pm 0.37$ \\
\hline P (\%) & $0.09 \pm 0.01$ & $0.09 \pm 0.02$ & $0.09 \pm 0.02$ & $0.11 \pm 0.01$ \\
\hline K (\%) & $1.33 \pm 0.27$ & $1.23 \pm 0.69$ & $1.32 \pm 0.56$ & $1.47 \pm 0.72$ \\
\hline N (\%) & $0.141 \pm 0.05$ & $0.218 \pm 0.06$ & $0.170 \pm 0.07$ & $0.105 \pm 0.02$ \\
\hline SOC (\%) & $0.89 \pm 0.11$ & $1.06 \pm 0.25$ & $0.94 \pm 0.15$ & $1.04 \pm 0.30$ \\
\hline OM (\%) & $1.54 \pm 0.20$ & $1.82 \pm 0.44$ & $1.62 \pm 0.25$ & $1.79 \pm 0.52$ \\
\hline
\end{tabular}

In the correlation analysis, we found significant positive correlation among the variables in Ghangaria and Tolma site. The PCA ordination of Ghangaria site and Tolma site showed no relation of Acer caesium and Salix sikkimensis with any variable of the F1 and F2 which is indicated as supplementary variable, respectively (Figs. 2 and 3). In the context of frequency, seedling, sapling and tree of S-aspect were highly correlated with seedling, sapling and trees of $\mathrm{N}$-aspects at both sites of the reserve (significant at $\mathrm{p} \leq 0.05$ ) (Tables 8 and 9). 
Table 8

Correlation matrix of floristic composition on the basis of frequency indicator at Ghangaria site, NDBR.

\begin{tabular}{|c|c|c|c|c|c|c|}
\hline Variables & NT & NSA & NSE & ST & SSA & SSE \\
\hline NT & 1 & $0.932 *$ & $0.943^{*}$ & $0.786 *$ & $0.727 *$ & $0.766^{*}$ \\
\hline NSA & & 1 & $0.935^{*}$ & 0.578 & $0.650 *$ & $0.744^{*}$ \\
\hline NSE & & & 1 & $0.667 *$ & 0.610 & $0.712 *$ \\
\hline ST & & & & 1 & $0.722^{*}$ & $0.757^{*}$ \\
\hline SSA & & & & & 1 & $0.843^{*}$ \\
\hline SSE & & & & & & 1 \\
\hline \multicolumn{7}{|c|}{ *. Correlation is significant at the 0.05 level (2-tailed). } \\
\hline $\begin{array}{l}\text { NT = North } \\
\text { South see }\end{array}$ & & apling; & lorth see & $T=$ Sou & $S S A=S$ & pling; S \\
\hline
\end{tabular}

Table 9

Correlation matrix of floristic composition on the basis of frequency indicator at Tolma site, NDBR.

\begin{tabular}{|lllllll|}
\hline Variables & NT & NSA & NSE & ST & SSA & SSE \\
\hline NT & 1 & $0.897^{*}$ & $0.866^{*}$ & $0.802^{*}$ & $0.809^{*}$ & $0.636^{*}$ \\
\hline NSA & & 1 & $0.921^{*}$ & $0.861^{*}$ & $0.818^{*}$ & $0.707^{*}$ \\
\hline NSE & & 1 & $0.881^{*}$ & $0.863^{*}$ & $0.798^{*}$ \\
\hline ST & & & 1 & $0.935^{*}$ & $0.831^{*}$ \\
\hline SSA & & & 1 & $0.946^{*}$ \\
\hline SSE & & & & 1 \\
* Correlation is significant at the 0.05 level (2-tailed). & & & \\
NT=North Tree; NSA=North Sapling; NSE= North seedling; ST= South Tree; SSA= South Sapling; SSE= \\
South seedling
\end{tabular}

Soil characteristics may severely influence the vegetation, while vegetation structure and composition also affect the soil properties. Selective absorption of nutrient element by different tree species and their capacity to return nutrients to the soil bring about changes in soil properties (Singh et al. 1986). The soil texture is an important factor which indicates how well a particular texture can hold the water. Values of the water holding capacity varied from $28.70 \pm 3.35 \%$ to $33.50 \pm 4.54 \%$ and $40.58 \pm 6.92 \%$ to $49.94 \pm 5.63 \%$ at Tolma and Ghangaria site, respectively. The values for water holding capacity in the present study are in the line of values reported earlier by various workers from the temperate region of Garhwal Himalaya (Sharma et al. 
2010, and Nazir et al. 2009). The overall water holding capacity increased with increasing clay content in the soil while where sand proportion was lesser, water holding capacity of the soil was low. The calculated values for moisture content ranged between $46.49 \pm 3.85$ to $63.77 \pm 4.77$ were slightly higher than values reported by Khera et al. (2001) for Kumaun Himalaya and Nazir (2009) for Garhwal Himalaya. Clay, silt and sand contents in the soil of the studied sites ranged from $0.87 \pm 0.12 \%$ to $0.88 \pm 0.06 \%, 34.65 \pm 2.71 \%$ to 50.4 \pm 5.45 and $46.88 \pm 2.70 \%$ to $63.98 \pm 8.27 \%$ for Ghangaria site, whereas Tolma site exhibits $6.88 \pm 2.80 \%$ to $7.82 \pm 1.41 \%, 27.20 \pm 3.16 \%$ to $33.01 \pm 4.11 \%$ and $60.11 \pm 4.13 \%$ to $64.99 \pm 3.95 \%$, respectively. The soil was recorded slightly acidic in nature as indicated the range between 6.28 to 6.94 and 6.54 to 6.77 at Tolma and Ghangaria site. In general, $\mathrm{pH}$ values for the $\mathrm{N}$-aspect were higher compared to contrasting S-aspect, which could be attributed to the coniferous leaf litters, and stone rocks and more precipitation. Soil phosphorus content among all the stands was found in decreasing order with the soil depth. The phosphorus content ranged between $0.09 \pm 0.02 \%$ to $0.11 \pm 0.01$ at both site. Values for available $\mathrm{K}$ observed between $1.23 \pm$ $0.69 \%$ and $1.33 \pm 0.27 \%$ at Ghangaria site, while Tolma site showed range between $1.32 \pm 0.56 \%$ and $1.47 \pm$ $0.72 \%$. Soil nitrogen ranged was found between $0.170 \pm 0.07$ and $0.218 \pm 0.06 \%$ at both sites. The values of total $\mathrm{N}$ in the present study are higher than the values recorded by Khera et al. (2001), Srivastava et al. (2005), and Semwal (2006), Pandey et al. (2001), Sharma et al. (2010a), Thadani and Ashton (1995), Nazir (2009), and Sharma et al. (2010c). This could be attributed to higher water holding capacity and heavy litter and humus accumulation in the upper layers of forest soil. The present results revealed that soil carbon $(0.89 \pm 0.11$ to $1.06 \pm 0.25 \%)$ and organic matter $(1.54 \pm 0.20$ to $1.82 \pm 0.44 \%)$ has increased with increasing altitude and similar findings were reported in earlier study from mountain terrain by various workers (Trumbore et al. 1996; Garten et al. 1999; and Bolstad and Vose 2001). Hence, increasing trends of soil organic matter (\%) with increasing altitude may be due to the constant carbon inputs and decreasing rate of carbon loss at different altitude (Table 7).

The study revealed that intense recruitment of seedling and sapling of Betula utilis and Rhododendron campanulatum along the altitudinal gradient up to the upper timberline may be due to the more favorable climatic conditions for growth during past decades, and/or to land use changes in the high-altitude regions projected the great potential for future vegetation advancement. This study also exhibited the continuous decrease in the diameter $(\mathrm{CBH})$ of trees and augmentation of sapling and seedlings of Betula utilis and Rhododendron campanulatum along an altitudinal gradient is clear indication that these species may move upward to the higher altitude. With increased global warming, the vegetation of high altitude areas would be expected to advance upwards, but yet the changes observed in both study areas have been limited to enhance the recruitment and growth of species rather than vegetation advancement. However, to confirm the shifting of vegetation in NDBR, the long-term studies are required through establishment of permanent plots with manual as well as automatic weather data recording set ups. The upper limit of survival of the plant species is still unknown from these areas since no long term scientific data available on one hand and at the same time as the region has been under high anthropogenic pressure during recent past.

\section{Conclusion}

Our results suggest to monitor the change in vegetation structure, species composition and regeneration pattern, we should establish permanent study plots in different forest types located along the elevational 
gradients for an effective and comprehensive monitoring programme to tracks the response of changing climate at both community and species level. In addition, many important tree species of the reserve have already been listed in the rare and endangered categories, i.e., Taxus baccata, Juniperus spp. and Betula utilis. These species are over exploited, legally or illegally, to a great extent and increased rates of destruction and the influence of a changing climate have made the situation worse. Therefore, it is necessary to development of appropriate weather and meteorological station in this sensitive and ecologically important area for regional projection of micro climatic condition and generation of scientific data on changing vegetation composition and advancement of the native species.

\section{Declarations}

\section{Acknowledgement}

The authors wish to acknowledge the Director, GBPIHED, Kosi-katarmal, Almora and Garhwal Regional Centre for providing necessary facilities and Uttarakhand State Forest Department for granting permission to work in the remote area. The authors also acknowledge the support of DST, SERB division, Govt. of India for funding this study. Sincere appreciation goes to the local inhabitants for their cooperation and help.

\section{Authors Contribution}

A. M. is first or primary author of the manuscript who developed the research concept and collecting and analyzing the data set. R.K.M. and S.S.B. was the supervisor of the research concept. He provided technical editing and critical suggestion to shape of the manuscript.

\section{Conflict of interest}

All the authors declare no "conflict of interest" in the present Manuscript.

\section{References}

1. Adhikari BS (2004) Ecological attribute of vegetation in and around Nanda Devi National Park. Pp. 3035. In: Biodiversity Monitoring Expedition Nanda Devi 2003. A Report to the Ministry of Environment and Forests, Govt. of India, Uttranchal State Forest Department, Dehradun.

2. Allen TR, Walsh SJ (1996) Spatial and compositional pattern of alpine treeline, Glacier National Park, Montana. Photogrammetric Engineering and Remote Sensing, 62 (11):261 - 268.

3. Austrheim G (2002) Plant diversity patterns in semi-natural grasslands along an elevational gradient in southern Norway. Plant Ecology, 161:193-205.

4. Baduni NP, Sharma CM (1996) Effect of aspect on the structure of some natural stands of Cupressus torulosa in Himalayan moist temperate Forest. Proc Ind Nat Sci Acad B62:345-352.

5. Bai F, Sang W, Axmacher JC (2011) Forest vegetation responses to climate and environment change: A case study from Changbai Mountain, NE China. Forest Ecology and Management 262:2052-2060.

6. Bisht AS, Bhat AB (2013) Vegetation structure and plant diversity relation in a sub alpine region of Garhwal Himalaya, Uttarakhand, India. African Journal of Plant Science 7(8):401-406. 
7. Bolstad PV, Vose JM (2001) The effects of terrain position and elevation on soil C in the southern Appalachians. In: Lal, R., Kimble, J. M., Follett, R. F., Stewart, B. A.) (eds). 45-51.

8. Borchsenius F, Nielsen PK, Lawesson JE (2004) Vegetation structure and diversity of an ancient temperate deciduous forest in SW Denmark. Plant Ecology 175:121- 135.

9. Chandra J, Rawat VS, Rawat YS, Ram J (2010) Vegetational diversity along an altitudinal range in Garhwal Himalaya. Internat J Biodivers Conservat. 2(1): 014-018.

10. Chaturvedi OP, Singh JS (1987) The structure and function of pine forest in central Himalaya. Dry matter dynamics. Annals of Botany 60:237-252

11. Curtis JT, Mclntosh RP (1950) The interrelations of certain analytical and synthetic phytosociological characters. Ecology, 31:434-455.

12. Curtis JT (1959) The Vegetation of Wisconsin. An ordination of plant communities, University Wisconsin Press, Madision Wisconsin, p.657.

13. Dar JA, Sundarapandian S (2016) Patterns of plant diversity in seven temperate forest types of Western Himalaya, India. Journal of Asia Pacific Biodiversity 9:280-292.

14. Devi LS, Yadava PS (2006) Floristic diversity assessment and vegetation analysis of tropical semievergreen forest of Manipur, northeast India. Tropical Ecology 47: 89-98

15. Dhar U, Rawal RS, Samant SS (1997) Structural diversity and representativeness of forest vegetation in a protected area of Kumaun Himalaya, India: implications for conservation. Biodiversity and Conservation 6: 1045-1062.

16. Dolezal J, Srutek M (2002) Altitudinal changes in composition and structure of Mountain -temperate vegetation: a case study from the western Carpathians. Plant Ecology 158: 201-221.

17. Gairola S, Rawal RS, Todaria NP (2008) Forest vegetation patterns along an altitudinal gradient in subalpine zone of west Himalaya, India. African Journal of Plant Science, 2: 42-48.

18. Gairola S, Sharma CM, Ghildiyal SK, Suyal S (2012) Chemical properties of soils in relation to forest composition in moist temperate valley slopes of Garhwal Himalaya, India. Environmentalist 32(4):512523.

19. Gairola S, Sharma CM, Rana CS, Ghildiyal SK, Suyal S (2010) Phytodiversity (Angiosperms and Gymnosperms) in Mandal-Chopta forest of Garhwal Himalaya, Uttarakhand, India. Nature and Science 8:1-17.

20. Gairola S, Sharma CM, Suyal S, Ghildiyal SK (2011a). Species composition and diversity in midaltitudinal moist temperate forests of the western Himalaya. Journal of Forest Science, 27:1-15.

21. Gairola S, Sharma CM, Suyal S, Ghildiyal SK (2011b). Composition and diversity of five major forest types in moist temperate climate of the western Himalayas. Forestry Studies in China 13:139-153.

22. Garten CT, Post WM, Hanson PJ, Cooper LW (1999) Forest soil carbon inventories and dynamics along an elevation gradient in the southern Appalachian Mountains. Biogeo., 45: 115-145.

23. Goldsmith GW, Smith JHC (1926) Some physico-chemical properties of spruce sap and their seasonal and altitudinal variation. Colorado College Pub. Stud. Gen. Ser., 137:171 pp.

24. Griggs RF (1938) Timberline in the northern Rocky Mountains. Ecology 19:548-564. 
25. Henle K, Davies KF, Kleyer M, Margules C, Settele J (2004) Predictors of species sensitivity to fragmentation, Biodiversity and Conservation 13: 207-251.

26. Holtmeier FK (2003) Mountain timberlines - ecology, patchiness, and dynamics. Advances in Global Change Research. Kluwer Academic Publishers, Dordrecht, Boston, London

27. Jackson ML (1958) Soil Chemical Analysis. Prentice Hall, Englewood Cliffs, New Jersey.

28. Joshi HC, Samant SS (2004) Assessment of forest vegetation and conservation priorities of communities in a part of Nanda Devi Biosphere Reserve, West Himalaya. Part 1. International Journal of Sustainable Development and World Ecology 11:326-336.

29. Khan ML, Rai JPN, Tripathi RS (1987) Population structure of some tree species in disturbed and protected subtropical forests of north-east India, Acta Oecologica, vol. 8, no. 3, pp. 247-255.

30. Khan SM, Harper D, Page S, Ahmad H (2011) Species and community diversity of vascular flora along environmental gradient in Naran valley: A multivariate approach through indicator species analysis. Pakistan Journal of Botany. 43:2337-2346.

31. Kharkwal G, Mehrotra P, Rawat YS, Pangtey YPS (2005) Phytodiversity and growth form in relation to altitudinal gradient in the Central Himalayan (Kumaun) region of India. Current Science. 89(5): 873-878.

32. Khera N, Kumar A, Ram J, Tewari A (2001) Plant biodiversity assessment in relation to disturbances in mid-elevational forest of Central Himalaya, India. Trop. Ecol., 42(1):83-95.

33. Krauchi N, Brang P, Schonenberger W (2000) Forests of mountainous regions: gaps in knowledge and research needs. Forest Ecology and Management 132: 73-82

34. Kunwar RM, Sharma SP (2004) Quantitative analysis of tree species in two community forests of Dolpha district, mid-west Nepal. Himalayan Journal of Science. 2:49- 52.

35. Mani MS (1978) Ecology and phytogeography of the high altitude plants of the Northwest Himalaya: Introduction to high altitude botany. Ultimo, Australia: Halstead Press. p. 205.

36. Marks PL (1974) The role of pine cherry (Prnnus pensylvania L) in the maintenance of stability in northern hardwood ecosystems. Ecological Monographs 44: 73-88.

37. McVicar TR, Korner C (2012) On the use of elevation, altitude and height in the ecological and climatological literature. Oecologia, 171:335-337.

38. Misra R.1968. Ecology Work Book.Oxford and IBH Publishing Calcutta.

39. Nazir T (2009) Estimation of site quality of important temperate forest covers on the basis of soil nutrient and growing stock in Garhwal Himalaya. D.Phil. Thesis, HNB Garhwal University, Srinagar (Garhwal), Uttarakhand, India.

40. Pandey A, Soccol CR, Rodriguez-León JA, Nigam P (2001) Production of organic acids by solid-state fermentation. In: Solid-state fermentation in biotechnology -fundamentals and applications. New Delhi: Asiatech Publishers. pp. 113-126.

41. Panthi MP, Chaudhary RP, Vetaas OR (2007) Plant species richness and composition in trans-Himalayan inner valley of Manang district, central Nepal. Himalayan Journal of Sciences 4:57-64.

42. Paul A (2008) Studies on diversity and regeneration ecology of Rhododendrons in Arunachal Pradesh, Ph.D. thesis, Assam University, Silchar, India phytosociological characters. Ecology 31: 434-455. 
43. Pritts MP, Hancock JF (1983). The effect of population structure on growth patterns of the weedy goldenrod Solidago pauciflos culose. Canadian Journal of Botany 61: 1955-1958.

44. Rana CS, Gairola S (2009) Forest community structure and composition along an 530 elevational gradient of Parshuram Kund area in Lohit district of Arunachal Pradesh, Indian. Nature and Science 8:44-52.

45. Raturi GP (2012) Forest community structure along an altitudinal gradient of district Rudraprayag of Garhwal Himalaya, India. Ecologia 2:76-84.

46. Rawal RS, Pangtey YPS (1994). High altitude forest vegetation with special reference to timberline in Kumaun central Himalaya, 353-399 p. In: Pangtey YPS, Rawal RS (Eds.). High Altitudes of the Himalaya. Gyanodaya Prakashan, Nainital, India.

47. Rawat GS, Kala CP, Uniyal VK (2001) Plant species diversity and community composition in the Valley of Flowers, National Park, Western Himalaya. pp. 277-290. In: P. C. Pande \& S. S. Samant (eds.) Plant Diversity of the Himalaya. Gyanodaya Prakashan, Nainital.

48. Saima S, Dasti AA, Abbas Q, Hussain F (2010) Floristic diversity during monsoon in Ayubia National Park district Abbottabad, Pakistan. Pakistan Journal of Plant Science 16:43-50.

49. Saxena AK, Singh JS (1984) Tree population structure of certain Himalayan forest associations and implications concerning their future composition. Vegetatio. 58: 61-69.

50. Schickhoff U (2005) The upper timberline in the Himalayas, Hindu Kush and Karakorum: A review of geographical and ecological aspects. In (Broll, G. and B. Keplin eds.) Mountain ecosystems. Studies in treeline ecology: 275-354, Springer, Berlin/Heidelberg/New York.

51. Semwal DP, Uniyal PL, Bhatt AB (2010) Structure, composition and dominance diversity relations in three forest types of a part of Kedarnath wildlife sanctuary, central Himalaya, India. Notulac Scientia Biologicae 2:128-132

52. Shaheen H, Ahmad N, Alam N, Ahmed K, Ullah Z (2011a) Phytodiversity and endemic richness in high altitude Rama valley, Western Himalayas, Northern Pakistan. Journal of Medicinal Plants Research 5(8):1489-1493.

53. Shaheen H, Khan SM, Harper DM, Ullah Z, Qureshi RA (2011b) Species diversity, community structure, and distribution patterns in western Himalayan alpine pastures of Kashmir, Pakistan. Mountain Research and Development 31:153-159.

54. Shaheen H, Ullah Z, Khan SM, Harper DM (2012) Species composition and community structure of western Himalayan moist temperate forests in Kashmir. Forest Ecology and Management. 278:138145.

55. Shankar U (2001) A case of high tree diversity in a Sal (Shorea robusta) dominated lowland forest of Eastern Himalaya: floristic composition, regeneration and conservation. Current Science, 81:776-86.

56. Shannon CE, Weaver W (1949)The Mathematical Theory of Communication. Urbana, IL: University of Illinois Press, Urbana.

57. Sharma CM, Baduni NP, Gairola S, Ghildiyal SK, Suyal S (2010) Effects of slope aspects on forest compositions, community structures and soil properties in natural temperate forests of Garhwal Himalaya. Journal of Forestry Research, 21: 331-337. 
58. Sharma CM, Butola DS, Ghildiyal SK, Gairola S (2013) Phytodiversity along an altitudinal gradient in Dudhatoli forest of Garhwal Himalaya, Uttarakhand, India. International Journal of Medicinal and Aromatic Plants. 3:439-451

59. Sharma CM, Ghildiyal SK, Gairola S, Suyal S (2009)Vegetation structure, composition and diversity in relation to the soil characteristics of temperate mixed broad-leaved forest along an altitudinal gradient in Garhwal Himalaya. Indian Journal of Science and Technology, 2 (2009), pp. 39-45.

60. Shaw CH (1909) The causes of timberline on mountains. Plant World, 12:169-181.

61. Sherman R, Mullen R, Haomin L, Zhendong F, Wang Yi (2008) Spatial patterns of plant diversity and communities in alpine ecosystems of the Hengduan Mountains, northwest Yunnan, China. Journal of Plant Ecology. 1:117-136.

62. Singh A, Gupta NK (2009) Assessment of floristic diversity and regeneration status of Cedrus deodara (Roxb.) Loud. Stands under forest management systems in Western Himachal Himalayas: A case study of Shimla district. Indian Journal of Forestry 32:45-54.

63. Singh DK, Hajra PK (1996) Floristic diversity. G.S. Gujral, V. Sharma (Eds.), Changing perspectives of biodiversity status in the Himalaya, British Council Division, British High Commission, New Delhi (1996), pp. 23-38.

64. Srivastava RK, Khanduri VP, Sharma CM, Kumar P (2005) Structure, diversity and regeneration potential of oak-dominant conifer mixed forest along an altitudinal gradient in Garhwal Himalaya. Ind. For., 131(12):1537-1553.

65. Tang CQ, Ohsawa M (1997) Zonal transition of evergreen, deciduous, and coniferous forests along the altitudinal gradient on a humid subtropical mountain, Mt. Emei, Sichuan, China. Plant Ecology 133:6378

66. Tanvir M, Murtaza G, Ahmad KS, Salman M (2014) Floral diversity of district Bagh, Azad Jammu and Kashmir Pakistan. Universal Journal of Plant Science 2:1-13.

67. Thadani R, Ashton PMS (1995) Regeneration of Banj oak (Quercus leucotrichophora A. Camus) in the central Himalaya. For. Ecol. Manag., 78:217-224.

68. Trumbore SE, Chadwick OA, Amundson R (1996) Rapid exchange between soil carbon and atmospheric carbon dioxide driven by temperature change. Science, 272:393-396.

69. Veblen TT, Stewart GH (1980) Comparison of forest structure and regeneration on Bench and Stewart Islands. New Zealand Journal of Ecology 3: 50-68.

70. Walkly A, Black IA (1934) An examination of the Degtjareff method for determining organic carbon in soil: Effect of variations in digestion conditions and of inorganic soil constituents. Soil Science, 63:251263.

71. Zhang JT, Li WRB (2006) Relationships between vegetation and climate on the Loess Plateau in China Folia Geobotanica, 41 (2006), pp. 151-163

72. Zhang JT, Ru W (2010) Population characteristics of endangered species Taxus chinensis var. mairei and its conservation strategy in Shanxi, China. Population Ecology, 52: 407-416

73. Zhang JT, Xu B, Li M (2013) Vegetation patterns and species diversity along elevational and disturbance gradients in the Baihua mountain reserve, Beijing, China. Mountain Research and Development 33:170- 
178.

Figures

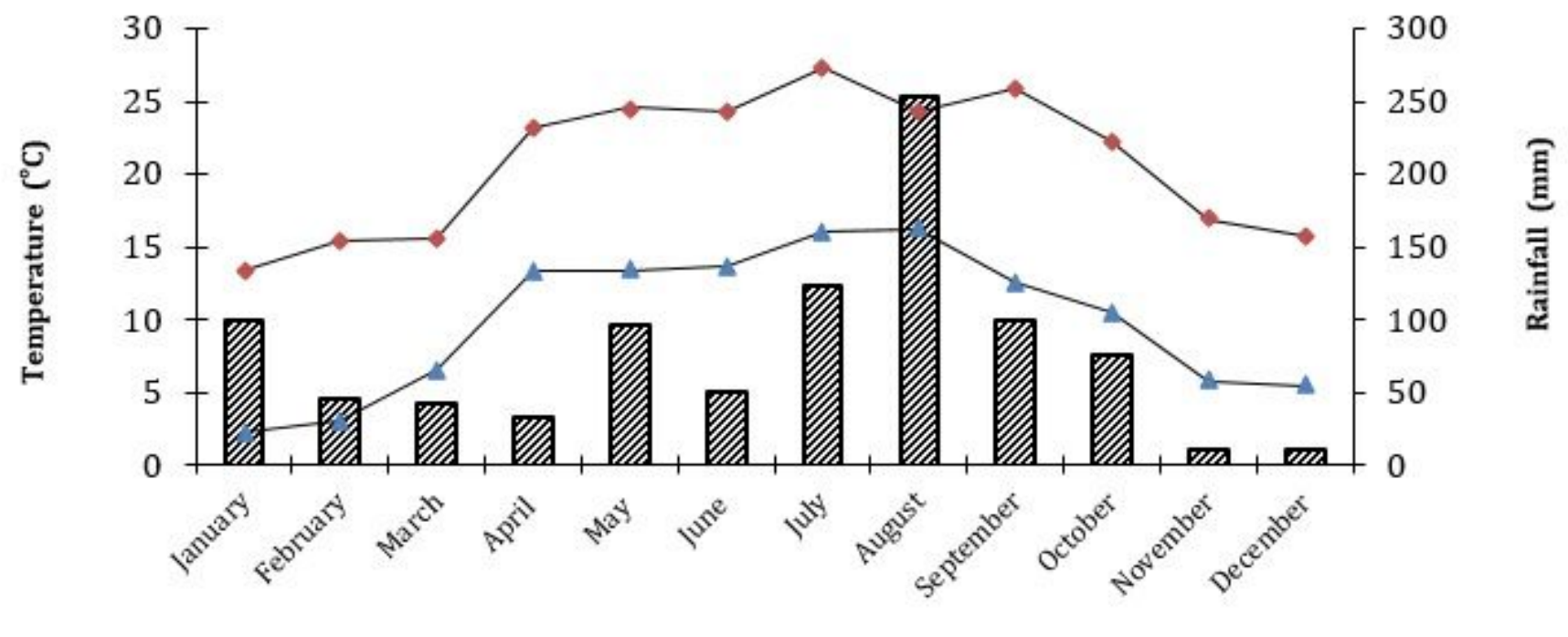

RIIIn Rainfall - - Maximum temperature $\quad \rightarrow-$ Minimum temperature

\section{Figure 1}

The annual rainfall occurs over a short period of two months (July-August) due to the strong influence of the monsoon. The maximum temperature ranges from 11 to $24 \mathrm{OC}$ and the minimum from 3 to $7.50 \mathrm{C}$ 


\section{Ghangaria site}

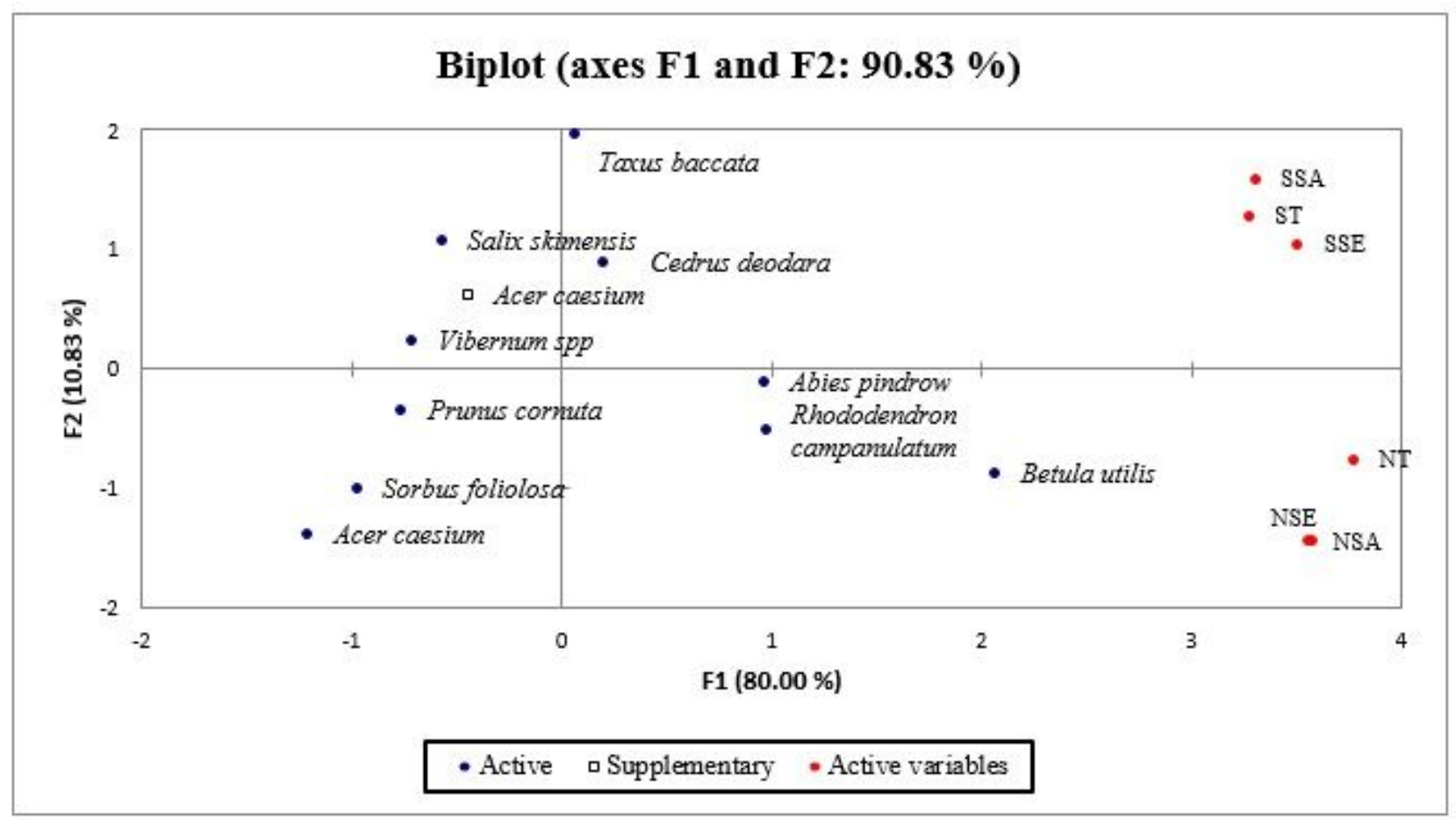

Tolma site

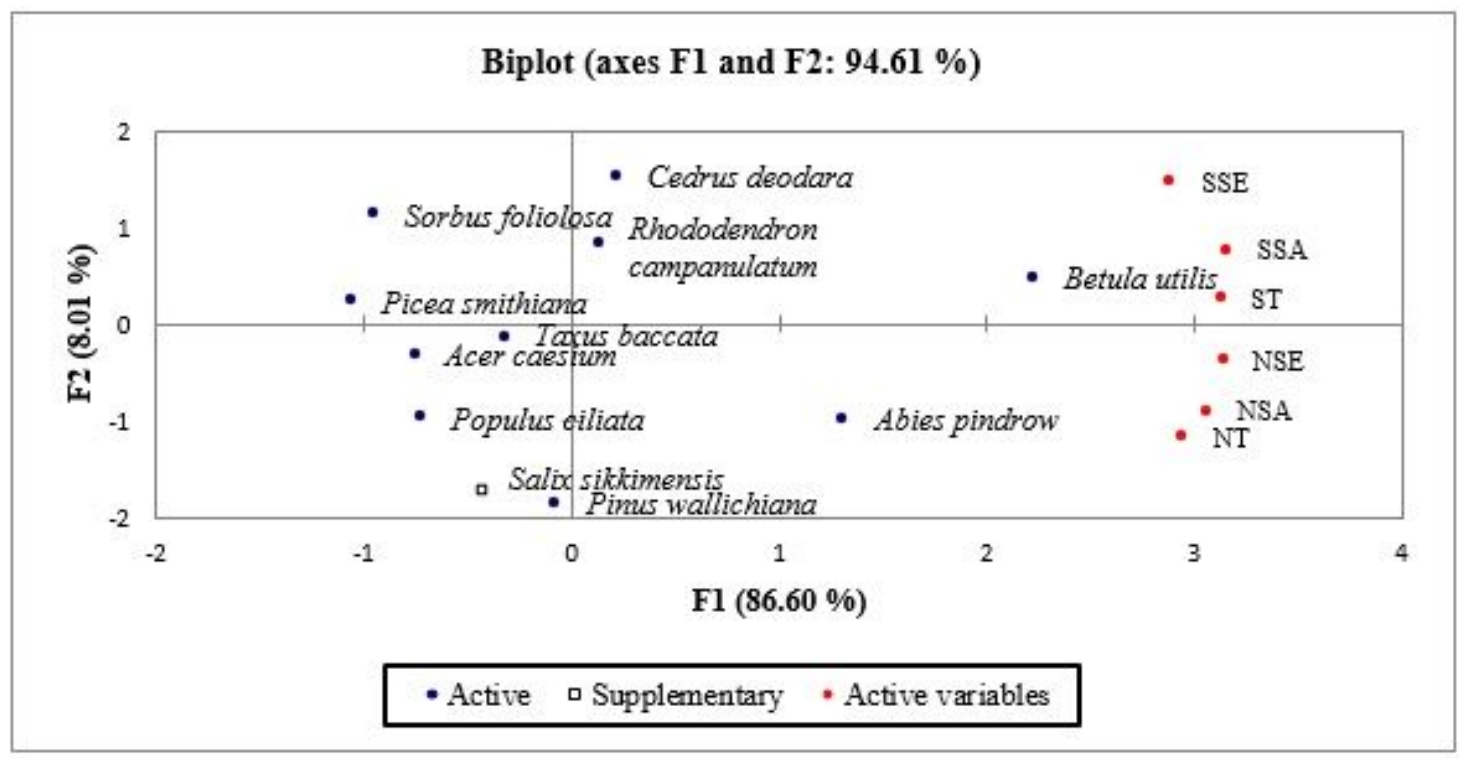

\section{Figure 2}

Positive correlation among the variables in Ghangaria and Tolma site. 